
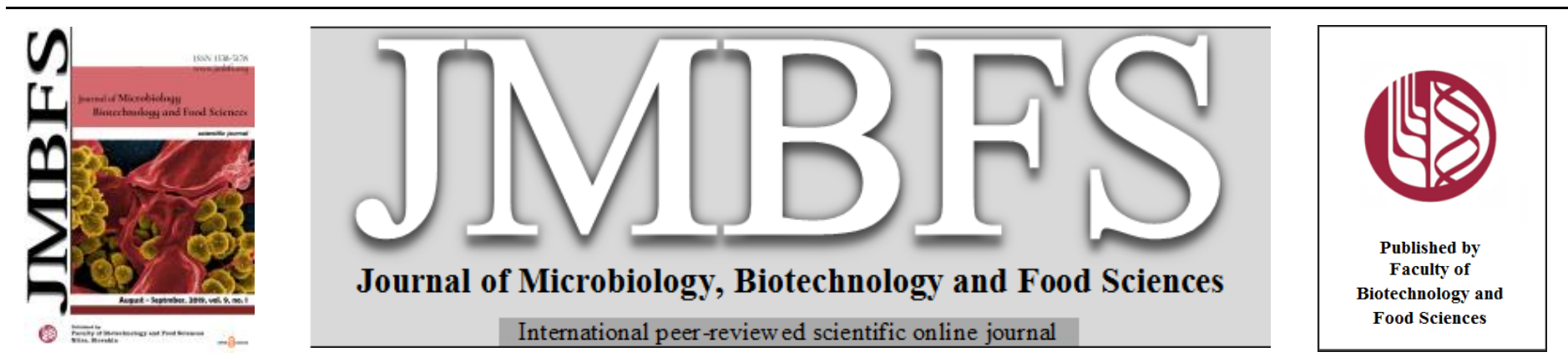

\title{
OCCURRENCE AND TOXIN GENE PROFILE OF BACILLUS CEREUS IN DAIRY PRODUCTS
}

\section{Yolande T.R. Proroga ${ }^{l}$, Federico Capuano ${ }^{1}{ }^{*}$, Silvia Castellano ${ }^{1}$, Angela Giordano ${ }^{l}$, Andrea Mancusi ${ }^{1}$, Elisabetta Delibato ${ }^{2}$, Stefano Dumontet ${ }^{3}$, Vincenzo Pasquale ${ }^{3}$}

\author{
$\operatorname{Address}(e s):$ \\ ${ }^{1}$ Istituto Zooprofilattico Sperimentale del Mezzogiorno, Department of Food Microbiology, Via Salute, 2 - 80055 Portici (Naples), Italy, +39-0817865117. \\ 2 Istituto Superiore di Sanità, Department of Veterinary Public Health and Food Safety, Viale Regina Elena, 299, 00161 Rome, Italy. \\ ${ }^{3}$ Università degli Studi di Napoli "Parthenope“, Department of Science and Technology, Centro Direzionale, Isola C4, 80143 Naples, Italy.
}

*Corresponding author: federico.capuano@ cert.izsmportici.it

doi: 10.15414/jmbfs.2019.9.1.58-62

\section{ARTICLE INFO}

Received 3. 8. 2018

Revised 12.3. 2019

Accepted 13. 3. 2019

Published 1. 8. 2019

Regular article open 2 access

\begin{abstract}
Bacillus cereus, a bacteria frequently associated with food spoilage, is responsible for 2 different foodborne illness in humans: a diarrheal disease, associated with cytotoxin $\mathrm{K}$, hemolysin BL and a non-hemolytic enterotoxin, and an emetic syndrome, associated with the cereulide toxin.

The aim of this study is to investigate the occurrence of B. cereus in 515 hard and soft cheeses collected in southern Italy. The strains were molecularly characterized for the presence of $h b l \mathrm{~A}, h b l \mathrm{C}, h b l \mathrm{D}, n h e \mathrm{~A}, n h e \mathrm{~B}, n h e \mathrm{C}, c y t \mathrm{~K}$, and ent $\mathrm{F} M$ genes, related to the production of enterotoxins (trimeric hemolysin BL, trimeric non-hemolytic enterotoxin, cytotoxin K and enterotoxin FM). One hundred thirty eight samples $(26.8 \%)$ were found contaminated by B. cereus. One hundred of the contaminated samples $(72.5 \%)$ showed a level of $B$. cereus contamination $\leq 10^{3} \mathrm{CFU} / \mathrm{g}$, whereas $9(6.5 \%)$ samples showed a contamination $>10^{5} \mathrm{CFU} / \mathrm{g}$. Seven different molecular profiles were found among the 138 strains of B. cereus isolated. The most common profile was nhe ABC-ent $\mathrm{FM}$, found in 42 strains, followed by the hblACD-nheABC-cytK-entFM, found in 33 strains, the nhe ABC-cytK-entFM, found in 24 strains, the hblACDnhe $\mathrm{ABC}-e n t \mathrm{FM}$, found in 11 strains, the hblACD-nhe $\mathrm{AC}$-ent $\mathrm{FM}$, found in 15 strains, and the nhe $\mathrm{C}$-entFM, found in 12 strains. Eleven strains did not harbored any of these genes.

In $7.2 \%(37 / 515)$ of samples, characterized by a bacterial contamination $>10^{3} \mathrm{CFU} / \mathrm{g}$, we found $B$. cereus strains harboring genes encoding for at least one complete enterotoxin.
\end{abstract}

Keywords: Concentration, enterotoxin genes, PCR, toxigenic profile, diarrheal disease

\section{INTRODUCTION}

The Bacillus cereus group comprises 7 closely related species of Gram positive spore-forming aerobic bacteria. In particular, B. cereus sensu stricto has been associated with food poisoning, B. thuringiensis (an insect pathogen the toxin of which proved to be an alternative to synthetic insecticides), B. anthracis (the agent of anthrax) and the other clinically less important species $B$. mycoides, $B$. pseudomycoides and $B$. weihenstephanensis. Two further species, named $B$. cytotoxicus and B. toyonensis, have been recently proposed (Guinebretiére $\boldsymbol{e t}$ al., 2013; Lapidus et al., 2008; Oren and Garrity, 2014).

B. cereus sensu stricto is responsible of 2 different types of food poisoning: diarrhoeal syndrome and the emetic syndrome. The diarrhoeal syndrome is caused by several heat-labile toxins including hemolysin BL ( $\mathrm{Hbl}$ ), nonhemolytic enterotoxin (Nhe), cytotoxin $\mathrm{K}(\mathrm{CytK})$, Bacillus cereus enterotoxin $\mathrm{T}$ (BceT) and enterotoxin FM (EntFM) (Beecher and Wong 1997; Lund and Granum, 1997; Schoeni and Wong, 2005; Tran et al., 2010), all of them produced during the vegetative bacterial growth in the small intestine. The emetic syndrome is caused by the production of the heat-stable peptide toxin cereulide (Ces) (Ehling-Schulz et al., 2015), that could be produced by cells growing in foodstuff. $\mathrm{Hbl}$ and Nhe are both tripartite toxins requiring the combined action of all components for the onset of the toxic action, while CytK and EntFM are monomeric proteins. The BceT toxic activity is still under debate, for it has been classified as enterotoxin on the basis of genetic and structural relations with other bacterial enterotoxins, rather than on the basis of clinical evidence (Agata $\boldsymbol{e t}$ al., 1995).

Though B. cereus poisoning is not usually a serious illness, some severe, and even lethal, cases have been reported (EFSA and ECDC, 2013, 2014; Lund et al., 2000). Emetic syndrome, characterized by nausea and vomiting, occurs few hours after the consumption of a contaminated meal, while diarrhoeal syndrome characterized by abdominal pain, watery or bloody diarrhoea and, occasionally, nausea and emesis, has an average incubation time ranging from 6 to $24 \mathrm{~h}$. The duration of the emetic syndrome is normally 12-24 h (Kramer and Gilbert, 1989). The infective dose of the diarrhoeal syndrome seems to be at least $10^{4}-10^{5}$
CFU/g (EFSA, 2005; Granum and Lund, 1997). However, considering that bacterial concentrations lower than $10^{4} \mathrm{CFU} / \mathrm{g}$ have been found able to trigger the onset the poisoning syndrome, any food containing between $10^{3} \mathrm{CFU} / \mathrm{g}$ and $10^{4}$ $\mathrm{CFU} / \mathrm{g}$ of $B$. cereus cannot be considered completely safe for consumption (Gilbert and Kramer, 1986). Almost all kind of food has been implicated in $B$. cereus foodborne poisoning, although the cases reported are mainly related to consumption of rice, vegetables, mixed food or buffet meals and fresh fruit (EFSA, 2016; EFSA and ECDC, 2013; Ombui et al., 2008). Due to its widespread environmental diffusion and its resistant endospores, B. cereus can also contaminate food during manufacturing, and survive the cooking temperature (Majed et al., 2016).

The presence of B. cereus in milk and in dairy product is well reported (Ahmed et al., 1983; Bonerba et al., 2010; De Santis et al., 2008; Johnston and Bruce, 1982; Larsen and Jørgensen, 1997; Molva et al., 2009). It is mainly due to heat resistance of its endospores and their ability to survive in milk and in milk powder, making dairies products possible causes of B. cereus food poisoning (EFSA and ECDC, 2014; Kumari and Sarkar, 2014; Wang et al., 2009; Zhang et al., 2016). In Europe, from 2010 to 2012, Bacillus outbreaks increased significantly (99 outbreaks in $2010 ; 220$ outbreaks in $2011 ; 259$ outbreaks in 2012); the reported rate in the EU was 0.04 and 0.05 per 100,000 inhabitants in 2011 and 2012, respectively (EFSA and ECDC, 2013, 2014). In Italy, notifications and reports of the B. cereus poisoning are scant (EFSA and ECDC, 2013; Martinelli et al., 2013; Zicari et al., 2011). The illness course, generally self-limiting and usually of not severe symptomatology, lead to underestimate its diffusion.

The distinguishing features among the species comprised in the B. cereus group are defined by genes located on plasmids or in the chromosome (Van der Auwera et al., 2007). The identification based on classical biochemical tools does not easily distinguish between the species in the B. cereus group (Bavykin et al., 2004; Stenfors et al., 2008). Considering that genes encoding for toxins associated with diarrhoeal disease are present in most Bacillus species, excepted B. anthracis (Mignot et al., 2001), it is probable that the poisoning caused by species other than B. cereus sensu stricto, are still under-reported. This is why, 
from a clinical standpoint, is preferable to characterize the isolates according to their virulence profiles, rather than to identify the species through to traditional biochemical tests (Cho et al., 2015; Granum et al., 1999).

The aim of this study is to evaluate the occurrence of B. cereus group in cheese and dairy products in southern Italy and to assess the risk of diarrhoeal food poisoning by means of the PCR based detection of genes related to B. cereus virulence.

\section{MATERIAL AND METHODS}

\section{Samples}

The study was carried out on 515 samples of dairy products collected from dairies, supermarkets and company canteens in southern Italy from January 2014 to June 2015. The samples were stored at $4{ }^{\circ} \mathrm{C}$ and analyzed within $24 \mathrm{~h}$ from sampling. The samples were classified, according to their water activity (Aw), into hard cheeses (Aw 0.79-0.93) and soft cheeses (Aw >0.96). The first group included seasoned cheeses and salted ricotta, while the latter included sof stretched curd cheeses, fresh cheeses and fresh ricotta (Table 1). The Aw measurements were carried out using the AquaLab 4TE (Decagon Devices, Pullman, WA, USA) in accordance with the manufacturer's instructions.

Table 1 Occurrence and enumeration of B. cereus in the dairy products.

\begin{tabular}{|c|c|c|c|c|c|c|c|}
\hline \multirow{2}{*}{ Dairy products } & \multirow{2}{*}{$\begin{array}{c}\text { Samples } \\
\text { analyzed }\end{array}$} & \multirow{2}{*}{$\begin{array}{c}\text { Positive } \\
\text { samples* }\end{array}$} & \multicolumn{5}{|c|}{ B. cereus $\mathrm{CFU} / \mathrm{g}$} \\
\hline & & & $\leq 10^{3}$ & $>10^{3}-10^{4}$ & $>10^{4}-10^{5}$ & $>10^{5}-10^{6}$ & $>10^{6}$ \\
\hline Soft stretched curd cheeses (Sc) & 331 & $81(24.5 \%)$ & 51 & 18 & 6 & 3 & 3 \\
\hline Fresh cheeses $(\mathrm{Sc})$ & 59 & $18(30.5 \%)$ & 18 & 0 & 0 & 0 & 0 \\
\hline Fresh ricotta $(\mathrm{Sc})$ & 33 & $11(33.3 \%)$ & 7 & 4 & 0 & 0 & 0 \\
\hline Salted ricotta $(\mathrm{Hc})$ & 52 & $14(26.9 \%)$ & 11 & 1 & 0 & 1 & 1 \\
\hline Seasoned cheeses $(\mathrm{Hc})$ & 40 & $14(35 \%)$ & 13 & 0 & 0 & 0 & 1 \\
\hline Total & 515 & $138(26.8 \%)$ & 100 & 23 & 6 & 4 & 5 \\
\hline
\end{tabular}

Sc: Soft cheese $($ Aw $>0.96)$, Hc: Hard cheese $(0.79 \leq \mathrm{Aw} \leq 0.93)$, * Detection limit: $100 \mathrm{CFU} / \mathrm{g}$

\section{Enumeration and identification of $\boldsymbol{B}$. cereus}

The enumeration of viable $B$. cereus were performed according to UNI EN ISO 7932:2005. In brief, $10 \mathrm{~g}$ of samples were homogenized in buffered peptone solution $(1: 10 \mathrm{~W} / \mathrm{V})$ and then diluted up to $10^{-4} ; 0.1 \mathrm{ml}$ of each dilution was transferred in Mannitol Egg Yolk Polymyxin Agar (MYP) (Oxoid, Basingstoke, UK) and incubated at $30{ }^{\circ} \mathrm{C}$ for $48 \mathrm{~h}$. Suspected colonies were counted and tested in order to evaluate their hemolytic activity on trypticase soy agar with $5 \%$ sheep blood (TSA+SB) (Biolife, Milano, Italy). Biochemical confirmatory assessment of the isolates were carried out by means of the automated system VITEK 2 (bioMerieux, Marcy l'Étoile, France), according to the manufacturer's instructions.

\section{Molecular assays}

$B$. cereus genes related to the production of enterotoxins responsible for the diarrheal syndrome and the molecular markers specific for $B$. thuringiensis were investigated according to the authors reported in Table 2. From each positive samples, one colony, grown on TSA+SB and biochemically identified as $B$. cereus, was molecularly characterized. The colonies were transferred in nutrient broth (Biolife) and after 4 hours of incubation $\left(30^{\circ} \mathrm{C}\right) 1 \mathrm{~mL}$ of culture broth was centrifuged for $3 \mathrm{~min}$ at $4,000 \mathrm{~g}$. The pellet was washed with $500 \mu \mathrm{l}$ of sterile DNase-free water, centrifuged a second time, re-suspended in $100 \mu \mathrm{l}$ of sterile MilliQ water, and heated $\left(98 \pm 1{ }^{\circ} \mathrm{C}\right.$ for $\left.10 \mathrm{~min}\right)$. Suspension was centrifuged again $(10,000 \mathrm{~g}$ for $5 \mathrm{~min})$ and the supernatant was collected and stored at $-20{ }^{\circ} \mathrm{C}$ until use. The PCR products were visualized by means of gel electrophoresis on $2.5 \%(\mathrm{w} / \mathrm{v})$ agarose under UV light.

The isolates were analyzed for the presence of cry genes (cry 1 and cry 9) related to the insecticidal activity of $B$. thuringiensis. The assay was performed by a modified Bravo et al. (1998) and Rosas-Garcia et al. (2008) protocol. In brief, for cry 1 detection, the annealing step was carried out at $54{ }^{\circ} \mathrm{C}$ instead of $52{ }^{\circ} \mathrm{C}$, whereas cry 9 detection was carried out through a SYBR green assay by means the iQ SyBr Green SuperMix (Bio-Rad laboratories, Hercules, CA, USA) using $0.2 \mu \mathrm{M}$ of each primer and $3 \mu \mathrm{L}$ DNA extract (neat and diluted 1/10) in a final volume of $25 \mu \mathrm{L}$. Thermocycling was done in a CFX96 deep well real time PCR detection System (Bio-Rad), with an initial denaturation at $95{ }^{\circ} \mathrm{C}$ for $3 \mathrm{~min}$, followed by 40 cycles of $95^{\circ} \mathrm{C}$ for $30 \mathrm{sec}$, and $54^{\circ} \mathrm{C}$ for 45 sec. Fluorescence was detected during the annealing/extension step at each PCR cycle. The presence of cry 9 was investigated using both agarose gel electrophoresis and melt-curve analysis.

Bacillus cereus ATCC 11778 PK/5 and B. thuringiensis subsp. aizawaii strain GC-91, were used as positive controls.

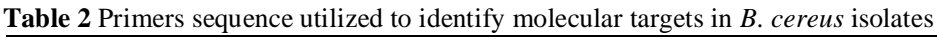

\begin{tabular}{|c|c|c|c|}
\hline $\begin{array}{c}\text { Target } \\
\text { gene }\end{array}$ & $\begin{array}{c}\text { Primer sequence } \\
\left(5^{\prime}-3^{\prime}\right)\end{array}$ & $\begin{array}{l}\text { Product size } \\
\text { (bp) }\end{array}$ & Reference \\
\hline$h b l \mathrm{C}$ & $\begin{array}{l}\text { F-CCTATCAATACTCTCGCAA } \\
\text { R-TTTCCTTTGTTATACGCTGC }\end{array}$ & 695 & Ngamwongsatit et al., 2008 \\
\hline$h b l \mathrm{D}$ & $\begin{array}{l}\text { F-GAAACAGGGTCTCATATTCT } \\
\text { R-CTGCATCTTTATGAATATCA }\end{array}$ & 1018 & Ngamwongsatit et al., 2008 \\
\hline$h b l \mathrm{~A}$ & $\begin{array}{l}\text { F-GCAAAATCTATGAATGCCTA } \\
\text { R-GCATCTTGTTCGTAATGTTTT }\end{array}$ & 884 & Ngamwongsatit et al., 2008 \\
\hline$n h e \mathrm{~A}$ & $\begin{array}{l}\text { F-TAAGGAGGGGCAAACAGAAG } \\
\text { R-TGAATGCGAAGAGCTGCTTC }\end{array}$ & 759 & Ngamwongsatit et al., 2008 \\
\hline nheB & $\begin{array}{l}\text { F-CAAGCTCCAGTTCATGCGG } \\
\text { R-GATCCCATTGTGTACCATTG }\end{array}$ & 935 & Ngamwongsatit et al., 2008 \\
\hline nhe $\mathrm{C}$ & $\begin{array}{l}\text { F-ACATCCTTTTGCAGCAGAAC } \\
\text { R-CCACCAGCAATGACCATATC }\end{array}$ & 618 & Ngamwongsatit et al., 2008 \\
\hline cyt $\mathrm{K}$ & $\begin{array}{l}\text { F-CGACGTCACAAGTTGTAACA } \\
\text { R-CGTGTGTAAATACCCCAGTT }\end{array}$ & 565 & Ngamwongsatit et al., 2008 \\
\hline ent $\mathrm{FM}$ & $\begin{array}{l}\text { F-GTTCGTTCAGGTGCTGGTTAC } \\
\text { R-AGCTGGGCCTGTACGTACTT }\end{array}$ & 486 & Ngamwongsatit et al., 2008 \\
\hline $\operatorname{cry} 1$ & $\begin{array}{l}\text { F- CTGGATTTACAGGTGGGGATAT } \\
\text { R-TGAGTCGCTTCGCATATTTGACT }\end{array}$ & $543-593$ & Bravo et al., 1998 \\
\hline cry 9 & $\begin{array}{l}\text { F-CGGTGTTACTATTAGCGAGGGCGG } \\
\text { R-GTTTGAGCCGCTTCACAGCAAATCC }\end{array}$ & $351-354 *$ & Rosas-Garcia et al., 2008 \\
\hline
\end{tabular}

*Melting temperature of the cry 9 amplicon $81.5 \pm 0.5{ }^{\circ} \mathrm{C}$ 


\section{Statistical analysis}

The statistical analysis was carried out by means of the EpiInfo ${ }^{\mathrm{TM}} 7$ software package (Centers for Diseases Control and Prevention, GA, USA). A two-tailed chi-square $(\chi 2)$ test and the Odds Ratio (OR) test were performed. P values $<0.05$ and an OR values $>1(95 \% \mathrm{CI})$ were considered as indicators of statistically significant difference among data.

\section{RESULTS}

\section{Microbiological assays}

Five hundred and fifteen dairy products were analyzed and $138(26.8 \%)$ of them were found contaminated by B. cereus strains (Table 1). The occurrence was higher in hard cheeses $(30.4 \%)$ than in soft cheeses $(26 \%)$. In particular, the higher frequency of contamination was observed in the seasoned cheeses $(35 \%)$, fresh ricotta $(33.3 \%)$, and fresh cheeses $(30.5 \%)$; whereas lower ones were observed in salted (seasoned) ricotta $(26.9 \%)$ and soft stretched curd cheeses $(24.5 \%)$ (Table 1). The positive samples were classified in 5 groups on the basis of their B. cereus concentration (Table 1): a) $\leq 10^{3} \mathrm{CFU} / \mathrm{g}(72.5 \%)$; b) $>10^{3}-10^{4}$ CFU/g (16.7\%); c) $>10^{4}-10^{5} \mathrm{CFU} / \mathrm{g}(4.3 \%)$; d) $>10^{5}-10^{6} \mathrm{CFU} / \mathrm{g}(2.9 \%)$; e) $>10^{6}$ $\mathrm{CFU} / \mathrm{g}(3.6 \%)$.

\section{Molecular assays}

Eleven out of the 138 isolates $(8 \%)$ were lacking of all genes responsible for enterotoxins production; the genes of more common detection were $n$ he $C$ and entFM (127/138, 92\%), followed by nheA $(125 / 138,90.6 \%)$, nheB $(110 / 138$ $79.7 \%$ ), and the $h b l$ components ( $h b l A C D)(59 / 138,42.8 \%)$. CytK was of less common detection $(57 / 138,41.3 \%)$ (Table 3$)$.

Table 3 Occurrence of enterotoxin genes in B. cereus strains.

\begin{tabular}{llcc}
\hline \multirow{2}{*}{ Toxin } & \multirow{2}{*}{ Gene } & \multicolumn{2}{c}{ Positive strains } \\
\cline { 3 - 4 } & & No. & \% \\
\hline \multirow{2}{*}{ Hemolysin BL } & hblC & 59 & 42.8 \\
& hblD & 59 & 42.8 \\
& $n h e A$ & 59 & 42.8 \\
\multirow{2}{*}{ Non-hemolytic enterotoxin } & $n h e B$ & 125 & 90.6 \\
& $n h e C$ & 110 & 79.7 \\
\hline Cytotoxin K & CytK & 57 & 92 \\
\hline Enterotoxin FM & EntFM & 127 & 41.3 \\
\hline
\end{tabular}

The complete trimeric toxins $\mathrm{Hbl}$ and Nhe were detected in $42.8 \%$ and $79.7 \%$ of the isolates, respectively. The 3 genes of the toxin $\mathrm{Hbl}$ were always jointly detected in the 59 positive strains and were lacking in the remaining 79 strains, whereas the 3 Nhe genes were differently linked (Table 4). The nhe $C$ gene was present alone in 2 isolates, while in 15 strains it was associated with nheA, which was never been detected alone. Finally, in agreement with the results of Ngamwongsatit et al. (2008), nheB was always detected together with both other 2 genes (nheAC). Forty-four isolates out of 138 (31.9\%) harbored the hblACD and $n h e \mathrm{ABC}$. In addition, EntFM and $n h e \mathrm{C}$ genes were always detected jointly $(127 / 138,92 \%)$. All the 57 isolates positive for $c y t K$ gene were also positive for entFM and $n h e C$, also $(\mathrm{P}<0.004)$.

The results of the molecular assays allowed to identify, in addition to the virulence profiles described by Ngamwongsatit et al. (2008), 2 new profiles presumably responsible for enteric disorders: hblACD-nhe $\mathrm{AC}-e n t \mathrm{FM}$ and $n h e \mathrm{C}$ entFM (Table 4).

Table 4 Molecular profiles in B. cereus stains from dairy products.

\begin{tabular}{|c|c|c|c|}
\hline \multirow{2}{*}{ Molecular profile } & \multirow{2}{*}{ Group } & \multicolumn{2}{|c|}{ Strains } \\
\hline & & No. & $\%$ \\
\hline nhe $\mathrm{ABC}$-entFM & $\mathrm{I}^{*}$ & 42 & 30.4 \\
\hline hblACD-nheABC-cytK-entFM & $\mathrm{II}^{*}$ & 33 & 23.9 \\
\hline nhe $\mathrm{ABC}$-cytK-entFM & III* & 24 & 17.4 \\
\hline hblACD-nheABC-entFM & $\mathrm{IV}^{*}$ & 11 & 8 \\
\hline hblACD-nheAC-entFM & V & 15 & 10.9 \\
\hline nheC-entFM & VI & 2 & 1.4 \\
\hline no gene coding for toxins detected & VII & 11 & 8 \\
\hline
\end{tabular}

* Molecular profile previously described (Ngamwongsatit et al., 2008)

Due to the prevalent detection of enterotoxigenic B. thuringiensis strains (Molva et al., 2009; Stenfors et al., 2008), we devoted a particular attention to the identification of the $B$. cereus group species: the cry 1 and cry 9 genes, which are the molecular fingerprint of B. thuringiensis, were never found in our 138 isolates.

\section{DISCUSSION}

B. cereus is a common soil inhabitant, often present in different food and foodstuff, including milk and dairy products (Larsen and Jørgensen 1997; Molva et al., 2009; Wang et al., 2009; Zhang et al., 2016). Despite the widely acknowledged occurrence in food and foodstuff, reports on the occurrence of $B$. cereus in cheese and in other dairy products are scant. Bonerba et al. (2010) analyzing catered food found $11.1 \%$ of the mozzarella-cheese samples positive for $B$. cereus, with a contamination always lower than $10^{6} \mathrm{CFU} / \mathrm{g}$. Data available from studies carried out in different countries show that the $B$. cereus contamination of dairy products in China (Wong et al., 1988) ranged from 52\% (icecream) to $2 \%$ (pasteurized milk). In Turkish cheese the prevalence of both $B$. cereus and B. thuringiensis (Molva et al., 2009) was found to be $12 \%$, while $B$. cereus and $B$. thuringiensis were detected in $6 \%$ and $22 \%$ of the analyzed samples, respectively. In Italy De Santis $\boldsymbol{e t}$ al. (2008) reported the pathogenicity profile of $B$. cereus isolated from Italian ricotta-cheese, pointing out that the 3 genes of the nhe operon were the most commonly detected (nheB $56 \%$, nheA $66.7 \%$, nhe $71.2 \%$ ), while the 3 genes of the toxin $\mathrm{Hbl}$ were less common ( $h b l \mathrm{~A}$ $28.8 \%$, hblC $31.8 \%$, hblD $47 \%$ ).

Although our study highlighted a relevant occurrence $(26.8 \%)$ of B. cereus in the analyzed dairy products, the contamination of the $89.1 \%$ of positive samples did not exceed $10^{4} \mathrm{CFU} / \mathrm{g}$. Among the samples showing a contamination $\geq 10^{4} \mathrm{CFU} / \mathrm{g}$ (10.9\%), 3.6\% harbored more than $10^{6}$ B. cereus $\mathrm{CFU} / \mathrm{g}$ (Table 1 ).

The absence of contamination by $B$. thuringiensis in our samples is worth noting, given its wide use in modern agriculture as pest suppressant and its frequent detection in cheese (Molva et al., 2009). It should be stressed that commercial biochemical identification systems, widely used by most authors to identify $B$. cereus in food, are unable to adequately discriminate between $B$. thuringiensis and B. cereus (Bavykin et al., 2004; Stenfors et al., 2008). This is why, we focused our study on the assessment of the virulence toxin gene profile of the isolates, founding 7 different molecular profiles among our 138 isolates (Table 4). Six of those gene profiles were often associated to virulence. The most common profile was found in 42 isolates $(30.4 \%)$, that showed positivity for $n h e A B C$ and $e n t F M$ genes (Group I). Other profiles were: a) strains harboring all genes investigated $(23.9 \%, 33 / 138)$ (Group II); b) strains positive for nheABC cyt $K$ and entFM genes $(24 / 138,17.4 \%)$ (Group III); c) strains positive for all genes codifying the 2 tripartite toxins $\mathrm{Hbl}$ and Nhe and for entFM gene $(11 / 138$, $8 \%$ ) (Group IV); d) strains positive for nheAC, hblACD, and entFM genes $(15 / 138,10.9 \%)($ Group V); e) strains harboring only nhe $C$ and entFM genes (Group VI) $(2 / 138,1.4 \%)$. In addition, 11 strains were lacking all these 8 genes (Group VII). The first 4 profiles were previously described by Ngamwongsatit $\boldsymbol{e t}$ al. (2008) (Table 4); the Group V is reported for the first time in this work as cause of possible food poisoning.

Isolates which were positives for all virulence genes considered (Group II), or at least for one of the 2 operons $h b l$ and nhe (Group I, III, IV and V), are probably the most dangerous for human. The strains harboring cyt $K$ gene (Group III), because of the necrotizing activity of the cyt $K$ toxin (Lund et al., 2000), should be considered of highly toxic. The Group VI, including 2 strains (1.4\%), harboring only one component of nhe complex (nheC) and the entFM gene, involved in bacterial shape, motility, adhesion to epithelial cells, biofilm formation, and vacuolization of macrophages (Tran et al., 2010), appear to be less virulent (Table 4). Therefore, 127 of the 138 isolates (92\%) analyzed in our study should be regarded as a potential source of enteric disorders of different severity.

In agreement with Bonerba et al. (2010), we found that the nhe complex, observed in $79.9 \%(110 / 138)$ of our isolates, was significantly more frequent than the $h b l$ complex, which was found in the $42.8 \%(59 / 138)$ of the isolates $\left(\chi^{2}=6.48\right.$; $\mathrm{P}<0.01)$. In addition, we found that all components of Hbl tripartite toxin were always simultaneously present in the positive strains. This was not the case for the nhe complex. It is interesting to highlight that the positivity regarding the $n h e B$ genes always matched with the presence of the genes encoding for the other 2 components of the Nhe toxin (nheAC). This finding, combined with the high occurrence of this gene among our isolates, suggests the protein NheB as suitable target for a new assay for the toxigenic characterization of B. cereus isolates, as its presence is always associated whit the proteins NheA and NheC, which make the toxin active.

Interestingly, B. cereus strains belonging to Groups IV, V and VI were mainly detected in samples with bacterial contamination $\leq 10^{3} \mathrm{CFU} / \mathrm{g}(26 / 28,92.9 \%)$; instead, the percentage of detection of $B$. cereus strains Groups I, II and III was higher in samples with $B$. cereus contamination $>10^{3}$ CFU/g $(35 / 99 ; 35.4 \%)$ $(\mathrm{P}<0.005 ; \mathrm{OR}=6.5)$. Gilbert and Kramer (1986) observed that food with a contamination of $B$. cereus cells around $10^{3} \mathrm{CFU} / \mathrm{g}$ represents a potential risk for human health, because $B$. cereus poisoning is not only related to the level of food contamination, being the number of sporulated cells withstanding the stomach acid barrier and the strains virulence profile are of great importance too (Rowan and Anderson, 1997). These results are of the higher interest as doses $\leq 10^{3} \mathrm{~B}$. cereus CFU/g have been found in food that caused enteric diseases (Gilbert and Kramer, 1986). In our study, most of the contaminated dairy products showed a concentration of $B$. cereus $\leq 10^{3} \mathrm{CFU} / \mathrm{g}$, while $27.5 \%$ (38/138) of contaminated samples showed a concentration $>10^{3} \mathrm{CFU} / \mathrm{g}$. In particular, 6 samples exceeded $10^{4}, 410^{5}$ and $510^{6}$ B. cereus $\mathrm{CFU} / \mathrm{g}$. 
The detection of 37 strains carrying toxin genes, in samples characterized by a bacterial contamination $>10^{3} \mathrm{CFU} / \mathrm{g}$, it is worth to note. These strains were classified in this work as Group I (17 strains), Group II (11 strains), Group III (7 strains), and Group VI (2 strains). Strains belonging to Groups II and III, are probably the most dangerous because of the presence of genes coding for the complete toxins.

\section{CONCLUSION}

EFSA reports (EFSA, 2013, 2014) highlight a steady increase of B. cereus outbreaks from 2010 to 2012 and points out that $5.3 \%$ of these outbreaks are related to cheese consumption. Moreover, food making, as well as the use of milk powder in dairy food production, increase the risk of poisoning, especially in case of not pasteurized raw material (Rowan and Anderson, 1997).

The results of this study support the EFSA findings about the $B$. cereus contamination of dairy products. In addition, $6.5 \%$ of positive samples fall in the area of high risk of food poisoning $\left(>10^{5} \mathrm{CFU} / \mathrm{g}\right)$ as indicated by EFSA (EFSA, 2016). We found that, even in low contaminated dairy products (around $10^{3} \mathrm{~B}$ cereus cells/g), the isolates express all the 6 virulence profiles identified in this work. So, a contamination around $10^{3} \mathrm{CFU} / \mathrm{g}$ cannot be considered completely safe, as reported by the EFSA Panel of Biological Hazards (EFSA, 2016). The number of $B$. cereus cells per $g$ of food, as well as the plain biochemica identification of strains, are not adequate tools for screening food poisoning risks In conclusion, in order to protect human health, it would be necessary to screen strains harboring virulence genes alongside the analysis of the concentration of $B$. cereus in food and foodstuff.

\section{REFERENCES}

Agata, N., Ohta, M., Arakawa, Y. \& Mori, M. 1995. The bceT gene of Bacillus cereus encodes an enterotoxic protein. Microbiology, 141, 983-988. http://dx.doi.org/10.1099/13500872-141-4-983

Ahmed, A.H., Moustafa, K. \& Marth, E.H. 1983. Incidence of Bacillus cereus in milk and some milk products. J. Food Prot., 46, 126-128.

EFSA \& ECDC. 2013. The European Union Summary Report on Trends and Sources of Zoonoses, Zoonotic Agents and Food-borne Outbreaks in 2011. EFSA J., 11(4), 3129, 250 pp. http://dx.doi.org/10.2903/j.efsa.2013.3129

EFSA \& ECDC. 2014. The European Union Summary Report on Trends and Sources of Zoonoses, Zoonotic Agents and Food-borne Outbreaks in 2012. EFSA J., 12(2), 3547, 312 pp. http://dx.doi.org/10.2903/j.efsa.2014.3547

EFSA. 2005. Opinion of the Scientific Panel on Biological Hazards on Bacillus cereus and other Bacillus spp in foodstuffs. EFSA J., 175, 1-48. http://dx.doi.org/10.2903/j.efsa.2005.175

EFSA. 2016. Risks for public health related to the presence of Bacillus cereus and other Bacillus spp. including Bacillus thuringiensis in foodstuffs - EFSA Panel on Biological Hazards (BIOHAZ) - EFSA J., 14(7), 4524 http://dx.doi.org/10.2903/j.efsa.2016.4524

Bavykin, S.G., Lysov, Y.P., Zakhariev, V., Kelly, J.J., Jackman, J., Stahl, D.A. \& Cherni, A. 2004. Use of 16S rRNA, 23S rRNA, and gyrB gene sequence analysis to determine phylogenetic relationships of Bacillus cereus group microorganisms. J. Clin. Microbiol., 42(8), 3711-3730 http://dx.doi.org/10.1128/JCM.42.8.3711-3730.2004

Beecher, D.J. \& Wong, A.C. 1997. Tripartite hemolysin BL from Bacillus cereus. Hemolytic analysis of component interactions and a model for its characteristic paradoxical zone phenomenon. J. Biol. Chem., 272(1), 233-239. http://dx.doi.org/10.1074/jbc.272.1.233

Bonerba, E., Di Pinto, A., Novello, L., Montemurro, F., Terio, V., Colao, V., Ciccarese, G. \& Tantillo, G. 2010. Detection of potentially enterotoxigenic foodrelated Bacillus cereus by PCR analysis. Int. J. Food. Sci. Tech., 45(6), 1310 1315. http://dx.doi.org/10.1111/i.1365-2621.2010.02257.x

Bravo, A., Sarabia, S., Lopez, L., Ontiveros, H., Abarca, C., Ortiz, A., Ortiz, M., Lina, L., Villalobos, F.J., Peña, G., Nuñez-Valdez, M.E., Soberón, M. \& Quintero, R. 1998. Characterization of cry genes in a Mexican Bacillus thuringiensis strain collection. Appl. Environ. Microbiol. 64(12), 4965-4972.

Cho, S.H., Kang, S.H., Lee, Y.E., Kim, S.J., Yoo, Y.B., Bak, Y.S. \& Kim, J.B. 2015. Distribution of toxin genes and enterotoxins in Bacillus thuringiensis isolated from microbial insecticide products. J. Microbiol. Biotechn., 25(12), 2043-2048. http://dx.doi.org/10.4014/jmb.1506.06025.

De Santis E.P.L., Foddai, A., Virdis, S., Marongiu, P., Pilo, A.L. \& Scarano, C. 2008. Toxin gene pattern in Bacillus cereus group strains isolated from sheep ricotta cheese. Vet. Res. Commun., 32 (Suppl 1), S323-S326. http://dx.doi.org/10.1007/s11259-008-9139-6.

Ehling-Schulz, M., Frenzel, E. \& Gohar, M. 2015. Food-bacteria interplay: pathometabolism of emetic Bacillus cereus. Front. Microbiol., 6, 704 http://dx.doi.org/10.3389/fmicb.2015.00704

Gilbert, R.J. \& Kramer, J.M. 1986. Bacillus cereus food poisoning. In Progress in our knowledge of foodborne disease during the life of the Food Research Institute, D.O. Cliver and B.A. Cochrane, eds., (Food Research Institute, University of Wisconsin-Madison, Madison, WI.), pp. 85-93.
Granum, P.E. \& Lund, T. 1997. Bacillus cereus and its food poisoning toxins. FEMS Microbiol. Lett., 157(2), 223-228. http://dx.doi.org/10.1111/j.15746968.1997.tb12776.x

Granum, P.E., O'Sullivan, K. \& Lund, T. 1999. The sequence of the nonhaemolytic enterotoxin operon from Bacillus cereus. FEMS Microbiol. Lett. 177(2), 225-229. http://dx.doi.org/10.1111/j.1574-6968.1999.tb13736.x

Guinebretière, M.H., Auger, S., Galleron, N., Contzen, M., De Sarrau, B., De Buyser, M.L., Lamberet, G., Fagerlund, A., Granum, P.E., Lereclus, D., De Vos, P., Nguyen-The, C. \& Sorokin, A. 2013. Bacillus cytotoxicus sp. nov. is a new thermotolerant species of the Bacillus cereus Group occasionally associated with food poisoning. Int. J. Syst. Evol. Micr., 63(PT1), 31-40. http://dx.doi.org/10.1099/ijs.0.030627-0

Johnston, D.W. \& Bruce, J. 1982. Incidence of thermoduric psychrotrophs in milk produced in the west of scotland. J. Appl. Microbiol. 52(3), 333-337. http://dx.doi.org/10.1111/j.1365-2672.1982.tb05061.x

Kovac, J., Miller, R.A., Carroll, L.M., Kent, D.J., Jian, J., Beno, S.M. \& Wiedmann, M. 2016. Production of hemolysin BL by Bacillus cereus group isolates of dairy origin is associated with whole-genome phylogenetic clade. BMC Genomics, 17, 581. http://dx.doi.org/10.1186/s12864-016-2883-Z

Kramer, J.M. \& Gilbert, R.J. 1989. Bacillus cereus and other Bacillus species. In Foodborne bacterial pathogens, M.P. Doyle, Ed., (Marcel Dekker, New York, NY), pp. 21-70.

Kumari, S. \& Sarkar, P.K. 2014. Prevalence and characterization of Bacillus cereus group from various marketed dairy products in India. Dairy Sci. \& Technol., 94(5), 483-497. http://dx.doi.org/10.1007/s13594-014-0174-5

Lapidus, A., Goltsman, E., Auger, S., Galleron, N., Ségurens, B., Dossat, C., Land, M.L., Broussolle, V., Brillard, J., Guinebretiere, M.H., Sanchis, V., NguenThe, C., Lereclus, D., Richardson, P, Wincker, P., Weissenbach, J., Ehrlich, S.D. \& Sorokin, A. 2008. Extending the Bacillus cereus group genomics to putative food-borne pathogens of different toxicity. Chem Biol Interact., 171(2), 236-249. http://dx.doi.org/10.1016/j.cbi.2007.03.003

Larsen, H.D. \& Jørgensen, K. 1997. The occurrence of Bacillus cereus in Danish pasteurized milk. Int. J. Food Microbiol., 34(2), 179-186. http://dx.doi.org/10.1016/S0168-1605(96)01182-8

Lund, T., De Buyser, M.L. \& Granum P.E. 2000. A new cytotoxin from Bacillus cereus that may cause necrotic enteritis. Mol. Microbiol., 38(2), 254-261. http://dx.doi.org/10.1046/j.1365-2958.2000.02147.x

Lund, T. \& Granum, P.E. 1997. Comparison of biological effect of the two different enterotoxin complexes isolated from three different strains of Bacillus cereus. Microbiology, 143(Pt 10$), \quad 3329-3336$ http://dx.doi.org/10.1099/00221287-143-10-3329

Majed, R., Faille, C., Kallassy, M. \& Gohar, M. 2016. Bacillus cereus biofilmssame, only different. Front. Microbiol., 7, 1054 http://dx.doi.org/10.3389/fmicb.2016.01054

Martinelli, D., Fortunato, F., Tafuri, S., Cozza, V., Chironna, M., Germinario, C., Pedalino, B. \& Prato, R. 2013. Lessons learnt from a birthday party: a Bacillus cereus outbreak, Bari, Italy, January 2012. Ann. Ist. Sup. Sanità 49(4), 391-394 http://dx.doi.org/10.4415/ANN $13 \quad 04 \quad 12$

Mignot, T., Mock, M., Robichon, D., Landier, A., Lereclus, D. \& Fouet, A. 2001 The incompatibility between the PlcR-and AtxA-controlled regulons may have selected a nonsense mutation in Bacillus anthracis. Mol. Microbiol., 42(5), 1189-1198. http://dx.doi.org/10.1046/j.1365-2958.2001.02692.x

Molva, C., Sudagidan, M. \& Okuklu, B. 2009. Extracellular enzyme production and enterotoxigenic gene profiles of Bacillus cereus and Bacillus thuringiensis strains isolated from cheese in Turkey. Food Control, 20(9), 829-834 http://dx.doi.org/10.1016/i.foodcont.2008.10.016

Ngamwongsatit, P., Buasri, W., Pianariyanon, P., Pulsrikarn, C., Ohba, M. Assavanig, A., Panbangred, W., 2008. Broad distribution of enterotoxin genes (hblCDA, nheABC, cytK, and entFM) among Bacillus thuringiensis and Bacillus cereus as shown by novel primers. Int. J. of Food Microbiol. 121(3), 352-356. http://dx.doi.org/10.1016/j.ijfoodmicro.2007.11.013

Ombui, J.N., Gitahi, J.N., Gicheru, M.M., 2008. Direct detection of Bacillus cereus enterotoxin genes in food by multiplex Polymerase Chain Reaction. Int. J. Integr. Biol. 2(3), 172-181

Oren, A., Garrity, G.M., 2014. List of new names and new combinations previously effectively, but not validly, published. Int. J. Syst. Evol. Micr. 64, 1-5 Rosas-García, N.M., Mireles-Martínez, M., Hernández-Mendoza, J.L., Ibarra, J.E., 2008. Screening of cry gene contents of Bacillus thuringiensis strains isolated from avocado orchards in Mexico, and their insecticidal activity towards Argyrotaenia sp. (Lepidoptera: Tortricidae) larvae. J. Appl. Microbiol. 104 (1), 224-230. http://dx.doi.org/10.1111/j.1365-2672.2007.03547.x

Rowan, N.J., Anderson, J.G. 1997. Maltodextrin stimulates growth of Bacillus cereus and synthesis of diarrheal enterotoxin in infant milk formulae. Appl. Environ. Microbiol. 63(3), 1182-1184.

Schoeni, J.L., Wong A.C., 2005. Bacillus cereus food poisoning and its toxins. J. Food Protect. 68(3), 636-648. http://dx.doi.org/10.4315/0362-028X-68.3.636 Stenfors, A.L.P., Fagerlund, A., Granum, P.E., 2008. From soil to gut: Bacillus cereus and its food poisoning toxins. FEMS Microbiol. Rev. 32(4), 579-606. http://dx.doi.org/10.1111/j.1574-6976.2008.00112.x 
Tran S.L., Guillemet E., Gohar M., Lereclus D., Ramarao N., 2010. CwpFM (EntFM) is a Bacillus cereus potential cell wall peptidase implicated in adhesion, biofilm formation, and virulence. J. Bacteriol. 192, 2638-2642. http://dx.doi.org/10.1128/JB.01315-09

UNI EN ISO, 2005. Microbiology of food and animal feeding stuffs. Horizontal method for the enumeration of presumptive Bacillus cereus. Colony-count technique at 30 degree C. ISO Norm 7932:2005. International Standardization Organization ed., Geneva, Switzerland.

Van der Auwera, G.A., Timmery, S., Hoton, F., Mahillon, J., (2007). Plasmid exchanges among members of the Bacillus cereus group in foodstuffs. Int. J. Food Microbiol. 113(2), 164-172. http://dx.doi.org/10.1016/j.ijfoodmicro.2006.06.030

Wang, M., Cao, B., Gao, Q., Sun, Y., Liu, P., Feng, L., Wang, L., 2009. Detection of Enterobacter sakazakii and other pathogens associated with infant formula powder by use of a DNA microarray. J. Clin. Microbiol. 47(10), 3178 3184. http://dx.doi.org/10.1128/JCM.00366-09

Wong, H.C., Chang, M.H., Fan, J.Y., 1988. Incidence and characterization of Bacillus cereus isolates contaminating dairy products. Appl. Environ. Microbiol. 54(3), 699-702.

Zhang, Z., Feng, L., Xu, H., Liu, C., Shah, N.P., Wei H., 2016. Detection of viable enterotoxin-producing Bacillus cereus and analysis of toxigenicity from ready-to-eat foods and infant formula milk powder by multiplex PCR. J. Dairy Sci. 99(2), 1047-1055. http://dx.doi.org/10.3168/jds.2015-10147

Zicari, G., Gorrasi, I., Di Gioia, S., Rossi, M.V., Traversi, D., Rivetti, D., Soardo, V., Cerrato, E., Carraro, E., Gilli, G., Ferrari, P., Magliola, R., 2011. Foodborne outbreaks surveillance in the Piedmont Region, Italy (2002-2009). Ig. Sanità Pubbl. 67(6), 721-742. 